\title{
O que ou quem eu sou, afinal de contas? Sou brasileiro ou uruguaio, professor?
}

\author{
Regina Maria de Souza e Alexandre Filordi de Carvalho*
}

Resumo: $\mathrm{O}$ presente trabalho terá como objetivo transformar em tema de reflexão as inquietações de duas crianças, Alicia e João, a respeito de sua nacionalidade; quer dizer, trazer em cena o sentimento ambíguo de pertença que possuem em relação a suas identidades. Diálogos com o pensamento filosófico serão realizados a respeito da fronteira, como lugar onde a naturalização da igualdade é posta por terra; naturalização na qual o conceito de identidade aparece como uma peça monolítica coesa e impenetrável. Defendemos o contrário: que a identidade é efeito de um processo constante, e sempre inacabado, de transformação subjetiva, pela mescla, pela angústia de não ser UM consigo mesmo e nem em relação aos outros. Apostamos, portanto, no universo múltiplo e incalculável do processo identitário, que torna único cada sujeito em seus dilemas.

Palavras-chave: identidade; língua; fronteira; política linguística; educação.

\section{What or who am I, after all? Am I Brazilian or Uruguayan, teacher?}

Abstract: The aim of the present paper is to bring about a reflection on the uneasiness of two children, Alicia and João, regarding their nationalities, that is, on their ambiguous feeling of belonging regarding their own identities. Dialogues based on philosophical thinking will be carried out about the frontier as a place where the naturalization of equality is extinguished, and naturalization, in which identity is perceived as a cohesive and impenetrable monolithic piece. The opposite is actually what we stand up for: identity is the effect of a never-ending, always unfinished process of subjective transformation, through miscellany, through anguish for not being ONE with oneself or with others. In short, we believe in the multiple and immeasurable universe of the identity process, which makes every subject unique concerning his or her dilemmas.

Key words: identity; language; frontier; linguistic politics; education.

* Professora do Departamento de Psicologia da Educação, Faculdade de Educação da Unicamp, Campinas, SP, Brasil. reginalaghi@hotmail.com.

Dedico este trabalho ao prof. Luis Behares e aos membros de sua linha de investigação na Universidade de la República, pela acolhida acadêmica, pela paciência com meus desacertos, pela elegância em nossas discussões e pela prontidão em ajudar.

* Professor de Filosofia da Educação, Universidade Federal de São Paulo (Unifesp), Brasil. afilordi@hotmail.com 


\title{
I. Fontes iniciais de inspiração e de diálogo sobre a língua
}

\author{
Toda noite, 200 milhões de pessoas sonham em \\ português. Estas são algumas delas. \\ (Sem autoria, apresentação do Documentário Língua: \\ vidas em português, 2002)
}

O documentário Lingua: vidas em português, do qual destacaremos duas reflexōes sobre a língua portuguesa, uma do escritor e biólogo Mia Couto e outra do escritor José Saramago, foi filmado em 2001 sob a direção de Victor Lopes; recebeu premiação nos dois países produtores - Portugal e Brasil -, além de ter sido apontado como um dos melhores documentários em associações de cinema internacionais. Tratou-se de uma coprodução Portugal-Brasil. Consiste em um filme de 105 minutos, rodado em seis países (Brasil, Moçambique, Índia, Portugal, França e Japão).

João Ubaldo Ribeiro (2010) realiza a seguinte súmula sobre o que a película põe em cena.

Em "Língua", a lusofonia, sobretudo, fala, surpreendida do cotidiano de personagens ilustres e anônimos de quatro continentes. Em cada um deles, o português amalgamou deuses, melodias, climas, ritmos. Misturou-se aos alimentos e às paisagens. Foi reinventado centenas de vezes e alimentado por sucessivos colonizadores, imigrantes e descendentes.

Em Portugal e Moçambique, no Brasil e em Goa, desenham-se os quadrantes de uma herança portuguesa, sempre surpreendente e permanentemente renovada. Acompanhando as trajetórias de seus personagens, e ouvindo suas experiências e sensações, suas memórias e esperanças diante do futuro, o documentário reproduz o movimento de uma língua que ganhou o mundo e que refaz seus caminhos na expectativa de se reencontrar.

Por isso, o filme é um documentário permanentemente em trânsito. Ao entrar e sair da vida dos personagens, o filme desvia-se das suas rotas cotidianas para encontrar cerimônias, casais, locais de trabalho, esquinas e paisagens, traçando retratos reveladores da cultura de cada um dos países visitados.

Nessa delicada peça cinematográfica, a língua portuguesa é posta em prosa por pessoas anônimas e, também, por outras de reconhecimento literário internacional, como sujeitos que amam a língua que falam e não se sentem obrigados a prestar contas disciplinares à linguística. De comum, ao longo das várias reflexôes postas em cena pelos protagonistas, tem-se o fato, também 
destacado por Orlandi recentemente (2009), de que a língua portuguesa concebeu descendentes que se "independentizaram" dela ao longo do tempo, de tal sorte que seria legítimo, e já em tempo, de falar, por exemplo, em "língua brasileira"; e eu acrescentaria outras possibilidades: língua portuguesa do Uruguai, português surdo, etc. Em cada terra fertilizada, e/ou em cada grupo humano inoculado pelo português, houve movimentos ricos de mestiçagem, de estreita e íntima relação, que provocaram mudanças no seio da língua que se pretendia impor como o espelho da língua portuguesa da corte de Portugal. Sincronicamente, a língua brasileira, filiada ao português, carrega em seu corpo as marcas das transformações que sofreu com as influências das línguas indígenas, africanas, de migração e de fronteira. Nos jogos de relações, o português, em cada terra que tocou, tornou-se outro.

Essa é a tônica provocativa do livro de Orlandi (2009) e do Documentário Lingua (2002).

A língua portuguesa é assim pensada por Mia Couto no referido documentário:

Acho que a língua portuguesa é hoje, talvez, uma das línguas europeias com maior vivacidade, com maior dinamismo. Não por causa de nenhuma essência especial do português, mas por causa de uma razão histórica do que aconteceu no Brasil em que, digamos, que Portugal deu origem a um filho maior que o próprio pais, né? A lingua passou a ser gerida por outros mecanismos de cultura. Depois aconteceram os países africanos que introduziram na língua portuguesa alguns fatores de mudança, coloração que tornam o português hoje uma língua que aceita muito, que é capaz de introduzir tonalidades e variações que enriquecem muito a língua portuguesa, não só do ponto de vista linguístico, mas o quanto ela pode traduzir culturas. Foi notado um processo histórico que está para além da língua, como estas culturas se mestiçaram e, de certa altura, o português ficou sem dono, quer dizer, ficou sem dono felizmente. E namorou e namorou no chão do Brasil e também namorou aqui na poeira de Moçambique, quer dizer, sujou-se, no sentido que o Manuel de Barros dá: sujou-se no sentido de que é capaz de casar com o chão. [...] No fundo não está a se viajar do ponto de vista geográfico..., mas está-se a viajar por pessoas. (grifos nossos).

De fato, a fronteira do Brasil com países sul-americanos coloca em evidência que o português, no Brasil, enamorou-se de vários grupos sociais, sujou-se, "no sentido de que é capaz de se casar com o chão" e com os diferentes grupos humanos que o português cativa como língua materna, como a língua que se apresenta para outros grupos linguísticos. Essas fronteiras não são espaciais 
nem políticas. São da ordem da identificação subjetiva, em que cada sujeito, na deriva da alienação que o desejo permite, faz-se pessoa em português, independente do que as instituições lhe impóem, cai no fascínio da sonoridade e da atração sintática da língua portuguesa, quer dizer, de sua Lei. Rende-se a ela. Os grupos humanos, diante de tal fascínio e captura, fazem do português algo maior do que os colonizadores pretendiam. Como argamassa e barro, a língua é esculpida por um desejo coletivo maior: o de cada comunidade fazer-se outra perante o Outro e de não ceder à Coroa ou ao Império. Ser outra. E assim se fez o português outro também com os surdos ou com os uruguaios de fronteira. Impregnado de vida... copulando com ela, o Português fez-se múltiplo: sujouse. Português do Uruguai... Português Surdo... outros portugueses fizeram-se cativos dessa gente toda que os recebeu. Submeteram-nos a uma ordem necessária: à ordem elástica, enigmática e amorosa da língua.

Retornando ao Documentário, José Saramago, ao final, tendo o Tejo à frente, com o sol encaixando-se nas profundezas do rio, o mesmo que abrigou as três naus que chegaram ao Brasil em 1500, conclui:

Quase me apetece dizer que não há uma língua portuguesa, há línguas em português. É uma língua que tinha que passar, como inevitavelmente tinha que passar, claro, por transformaçôes, segundo os lugares, segundo como a falam, segundo as culturas, as influências... Mas isto não tira a evidência da existência do corpo da língua portuguesa, mas é um corpo espalhado.

De fato, por mais singular que seja quando se mescla, a língua portuguesa cristalizou marcas sintáticas em suas línguas filiadas, o que a torna, de forma instigante, simultaneamente, mesma e radicalmente diferente de si, impura, sujeita a permanentes mudanças que sofrem restrições morfossintáticas e fonéticas.

O que queremos enfatizar aqui, portanto, é a riqueza, própria da língua, de não se fazer UMA, de misturar-se com outras, de tornar-se múltipla e de fazer incidir essa multiplicidade na subjetividade do sujeito que se divide com ela e por ela e não pode jamais se tornar UM com qualquer objeto de desejo.

Sem desconsiderarmos a relevância tática, do ponto de vista político, de produzir a ilusão de uma e apenas uma língua nacional, no que diz respeito ao sujeito, a identificação com iguais - com outros brasileiros que, formalmente, do ponto de vista da lógica clássica, falariam supostamente a mesma língua -, declarar-se "brasileiro" ou "uruguaio", negar-se brasileiro para fazer-se uruguaio (e vice-versa) faz parte de um necessário processo identificatório, ao menos enquanto convivermos com as atuais configurações geopolíticas dos estados nacionais. 
Indo mais além, apostamos na tese, já defendida por outros (Rajagopalan, 1998), de que convivemos com as chamadas línguas como se elas existissem de fato no mundo real, crescemos naturalizando a ideia de que falamos uma e mesma língua; em contraparte, temos o conforto de termos uma nacionalidade e de vê-la registrada em um passaporte ou documento de identidade, sem o qual não migramos para outros países.

Como sabemos, a grande maioria das pessoas foi educada para acreditar que faz parte de uma só nação, em relação à qual as instituições governamentais, os meios de comunicação, a família, a escola e a religião cativam cada novo sujeito; levam-no a amá-la e a lutar por ela, a identificá-la como se fosse entidade similar ao próprio pai e/ou mãe — as expressões terra paterna, língua materna e outros clichês trazem para a língua esse movimento de captura do desejo por essa abstração tão investida de poder chamada Nação.

Neste trabalho, procuraremos discutir o que experienciamos com duas crianças e colocar em questão como entendemos o que seja "identidade linguística".

\section{Identidade linguística}

\section{O que pode esta língua? (Caetano Veloso, Língua)}

O que quer,

A identidade, em linguística, refere-se à noção de unidade, isto é, dos limites e das características intrínsecas, pois constitutivas, que se atribuem a uma língua para distingui-la de uma outra.

Classicamente, como estratégia para delimitar os aspectos formais de uma língua, os linguistas, desde há muito, têm criado dicotomias como "língua" e "fala", como faz Saussure em seu curso de 1916 (1993); ou "competência" e performance, como Chomsky (1965), isso para tentarem driblar o fato de que, no acontecimento singular de um ato enunciativo, algo sempre escapa àquilo previsto pela maquinaria da linguística. Ao excedente tem-se denominado performance, entendida como a atualização do sistema linguístico já preexistente na mente do sujeito (Chomsky, 1965); ou fala, compreendida como um conjunto multifacetado e heterogêneo de elementos que, como tal, dificilmente se enverga à formalização (Saussure, 1993).

A linguística tem tomado para si estabelecer os atributos objetivos para que um sistema possa ser qualificado como uma identidade linguística - o que para Chomsky seria a competência e para Saussure, a língua, e não a fala. No entanto, basta que se pergunte a um linguista, como Mario Pei (1965, p. 47) propõe: "Qual é exatamente a diferença de uma língua de um dialeto? [...] Até 
mesmo os lingüistas se abstêm de responder e com razão. Quando uma língua é submetida a uma análise microscópica, percebe-se que é infinitamente diversificada".

Esta pergunta é ainda mais difícil de ser respondida, quando se trata de línguas que estão em contato em áreas geograficamente contíguas, como acontece entre o português e o espanhol em regiôes de fronteira. Durante séculos, formas linguísticas foram cristalizadas no encontro entre essas línguas. Como diria Manuel de Barros, o português sujou-se com o espanhol e produziu uma língua ágrafa distinta da língua portuguesa do Brasil - o português do Uruguai. Formas sintáticas sofreram mudanças, por exemplo, na maneira característica de flexionar gênero: "nóis cumemo bananas, maçã e laranja". A marca de plural em "bananas" é o suficiente para justificar a invariância de número dos substantivos subsequentes; basta um deles - o primeiro - estar flexionado, para que os demais se assujeitem à ordem plural "maçâ" e "banana", em vez do gramaticalmente padrão: "maçãs" e "bananas". Algo similar ocorre em: "meu irmão tem umas camisa".

Há quem possa argumentar que há, no português coloquial, também uma tendência a simplificar ou omitir as flexôes de número nas sentenças nominais e que, portanto, as ocorrências acima aplicam-se não apenas ao português do Uruguai. Isso está correto e revela que, até por contiguidade geográfica e humana, as semelhanças, em ambos os casos - o do português do Uruguai e o do português coloquial do Brasil -, marcam distância do português-padrão. Todavia, a omissão de marcas plurais e a cristalização desse mecanismo na fronteira merecem acompanhamento, a fim de serem registrados os movimentos singulares da língua em sua diacronia. Uma análise meridiana das características do "português do Uruguai" pode ser lida em Brovetto, Geymonat e Brian (2007). Esses autores também apontam, como característica do português do Uruguai, a simplificação da marca do plural.

Esta propensão a submeter-se a um mecanismo econômico próprio põe em suspeição o fato de que a nossa língua tenha uma identidade imutável, uma gramática única. Talvez o mais adequado fosse afirmar que o português se faz em muitos portugueses: o dos surdos, o do Uruguai, o das classes populares, o de Goa, o de Moçambique... o de tantos sujeitos que, à noite, sonham em seu próprio português.

O conceito de um sujeito "falante nativo de uma língua", como apontou Rajagopalan (1998), é igualmente problemático, pois ele é uma abstração, dado que os homens reais pertencem a comunidades pluralistas, nas quais o contato interlinguístico tem sido, ainda mais com a presença da internet, desestabilizador da pureza da língua. Desse modo, para os formalistas, o falante deixa de ser um informante fidedigno em condiçōes de auxiliar o linguista a 
estabelecer as fronteiras de uma língua. A fim de evitar a "contaminação" da inocência do falante, em vários momentos presenciamos bravatas ruidosas, protagonizadas por destacados nomes ligados à linguística ou à literatura, contra o ingresso no português de palavras provenientes do inglês e idiomas europeus. Entretanto, o que essas contendas colocam a nu é o efeito da invenção do "indivíduo", no século XVIII, e a alienação em relação à ilusão da existência de um falante nativo imune à mudança, como revela Rajagopalan (1998, p. 30):

O falante nativo individual é, no âmbito da lingüística, uma entidade plenamente totalizada, além de ser, como já vimos, pura, incorruptível, autêntica e estável.

Não é difícil rastrear a genealogia do falante nativo na lingüística moderna. Por trás do conceito do falante nativo na lingüística está a invenção do século XVIII do chamado "indivíduo". [...] no começo do período moderno o conceito de "identidade" começou a ser visto cada vez mais em termos essencialistas. O indivíduo era, desse momento em diante, um eu constituído de forma única, cuja realização suprema - aquela que, na visão de Kant, no fim prepararia o caminho da emancipação daquele indivíduo - foi a auto-consciência cartesiana.

Retirando-se a ideia de individualidade, o que temos é o fato de que todas as línguas têm uma tendência ilimitada para a dispersão e a hibridização. Se isso ocorre, é também porque o homem, ser falante, é movido para a dispersão e a hibridização - haverá nele uma falta constitutiva da qual a língua é efeito. Dito de outro modo, um indivíduo, ou seja, um organismo indiviso, não dividual, como unidade estável de caracteres que se mantêm estáveis, é uma ficção ainda maior, ou tão grande como algo que se denomine identidade linguística.

A identidade de um indivíduo se constrói na língua e através dela. Isso significa que o indivíduo não tem uma identidade fixa anterior e fora da língua. Além disso, a construção da identidade de um indivíduo na língua e através dela depende do fato de a própria língua em si ser uma atividade em evolução e vice-versa. Em outras palavras, as identidades da língua e do indivíduo têm implicações mútuas. (Rajagopalan, 2004, p. 41-42)

A insistência na defesa de que há uma e só uma língua nacional, bem como a fabricação de identidades, é uma estratégia que nutre interesses ideológicos.

Talvez a próxima grande revolução na lingüística resulte da constatação, por parte dos teóricos, de que muito dos incontroláveis fenômenos que desafiam as teorias contemporâ- 
neas só começaram a fazer sentido, ao que tudo indica, quando começamos a levar seriamente em conta a possibilidade de identidades proteiformes e quem sabe, das identidades "vira-latas" de Rushdie, o que significa identidades em permanente estado de fluxo. (Idem, p. 42, grifo nosso)

\section{Alicia: "eu não sei português, mas gostaria de saber, só posso escrever em espanhol"}

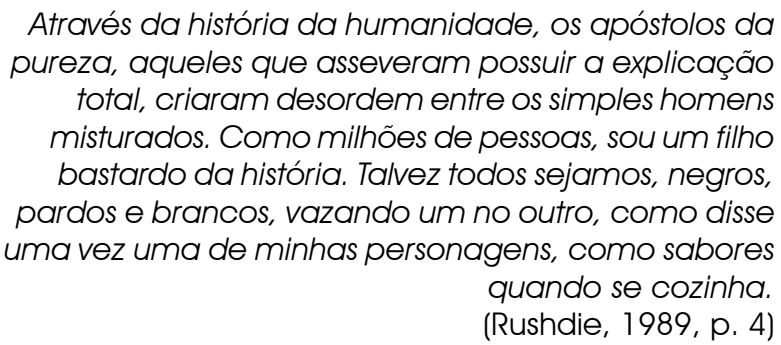

Alicia era uma criança de 9 anos. Residia em Minas de Corrales, cidade uruguaia de aproximadamente três mil habitantes, cujo nome deriva das minas que foram muito exploradas por volta dos anos 80 do século XIX. Pertence ao Departamento de Rivera, a $90 \mathrm{~km}$ da cidade uruguaia de Rivera, que tem uma contiguidade geográfica com Santana do Livramento, cidade brasileira. Local calmo, ocupando um espaço territorial cortado por uma única avenida principal - a Davison -, cujo nome é uma homenagem a um de seus cidadãos e médicos mais proeminentes: Dr. Francisco Davison (1853-1921).

A assimetria, em termos de prestígio masculino, em relação à mulher de Minas de Corrales pode ser vista no monumento mais conhecido do vilarejo, conforme fotos que virão parágrafos abaixo. Do ponto de vista econômico, as principais rendas provêm, atualmente, do setor agropecuário ou de pequenos comércios. Pouca distinção econômica é perceptível entre as pessoas - para um estrangeiro desavisado, poderia parecer que há uma apenas classe social. Todavia, se, do ponto de vista econômico, não se observa uma distinção digna de nota, do ponto de vista social, algumas marcas produzem diferenças. Por exemplo: ser uma mulher casada, em oposição a uma solteira, é visto como um sinal de maior consideração social. Ser casada e não trabalhar para os outros, mas para o próprio marido e filhos, é indício de prestígio, de estar bem casada e provida por seu homem. Falar o espanhol como os uruguaios da capital do país é a expressão, na fala, de um prestígio social só possível para os considerados culturalmente diferenciados ou inteligentes. Assim era a mãe de Alicia: morava em 
uma casa muito simples, era uma mulher "abnegada", não trabalhava para fora e orgulhava-se de falar o espanhol, de entender mal o português e de ser distinta daqueles que falavam a língua dos pobres: o português da fronteira (que não pode ser confundido com a mescla temporária de contato que chamamos vulgarmente de "portunhol"). Alicia tinha mais dois irmãos. Entre a primeira autora deste artigo, Regina, e Alicia estabeleceu-se uma relação imediata. A menina sabia o tema da pesquisa de Regina: encontrar em Minas de Corrales quem falasse e entendesse o português. Alicia conversava com Regina em espanhol e lhe dizia que entendia pouco o português, a língua em que Regina, preferencialmente, acabava conversando com ela. Sem parecer um paradoxo para a protagonista, Alicia negava conhecer a língua que escutava...

A vivaz menina uruguaia não queria casar: pensava em trabalhar, comprar uma moto e "sair por aí". Nada tinha de abnegada. Seus sonhos, e os sonhos sempre têm um delicado aroma delirante, era de uma mulher autônoma. Ser "independente" parecia ser o seu sonho mais imediato, ou seja, ser dela mesma, por ela mesma, compartilhando sua companhia com aqueles que lhe fossem similares ou fraternos e sair rodando com sua moto pelo mundo afora. Mas quem seria seu fraterno: a mulher abnegada de Minas de Corrales, que era a sua mãe, ou as "decididas e independentes" (como as qualificava) garotas de Montevidéu? As brasileiras ou as uruguaias?

Além dessa vontade, Alicia, às vezes, parecia irritar a mãe, tentando falar em português. Era bem-sucedida: a mãe deixava transparecer claramente seu incômodo, quando Alicia se arriscava no português. Em situações assim, uma bravata rápida (im)punha-se entre ambas, mas, invariavelmente, acabava em risos das duas.

Regina, um dia, solicitou a Alicia que lhe ensinasse a escrever o espanhol, o que foi aceito pela garota. Ambas caminhavam pela Av. Davison várias vezes durante a semana e, em algumas delas, sentavam-se próximas ao monumento abaixo.

Regina pedia que Alicia lesse em espanhol o que estava escrito nos outdoors ou nas placas de avisos, de informações ou de homenagens a personagens célebres. Uma vez pediu a Alicia para explicar-lhe o que seria uma mulher "abnegada”, palavra escrita abaixo do retrato de Ana Davison, esposa do médico Dr. Francisco Davison.

Alicia respondeu em espanhol "Abnegada é ser uma mulher que faz tudo o que esperam dela, que casa para servir o homem, que se importa com que os outros dizem dela e que é... abnegada. Por isto quero uma moto, ela pode me levar onde quero estar. Descobrir outros caminhos..." (riso sutil de Alicia, 18 de agosto de 2008).

Nas andanças pela cidade, Regina percebia a coexistência das línguas portuguesa e espanhola em espaços demarcados, como na única lanhouse que há 

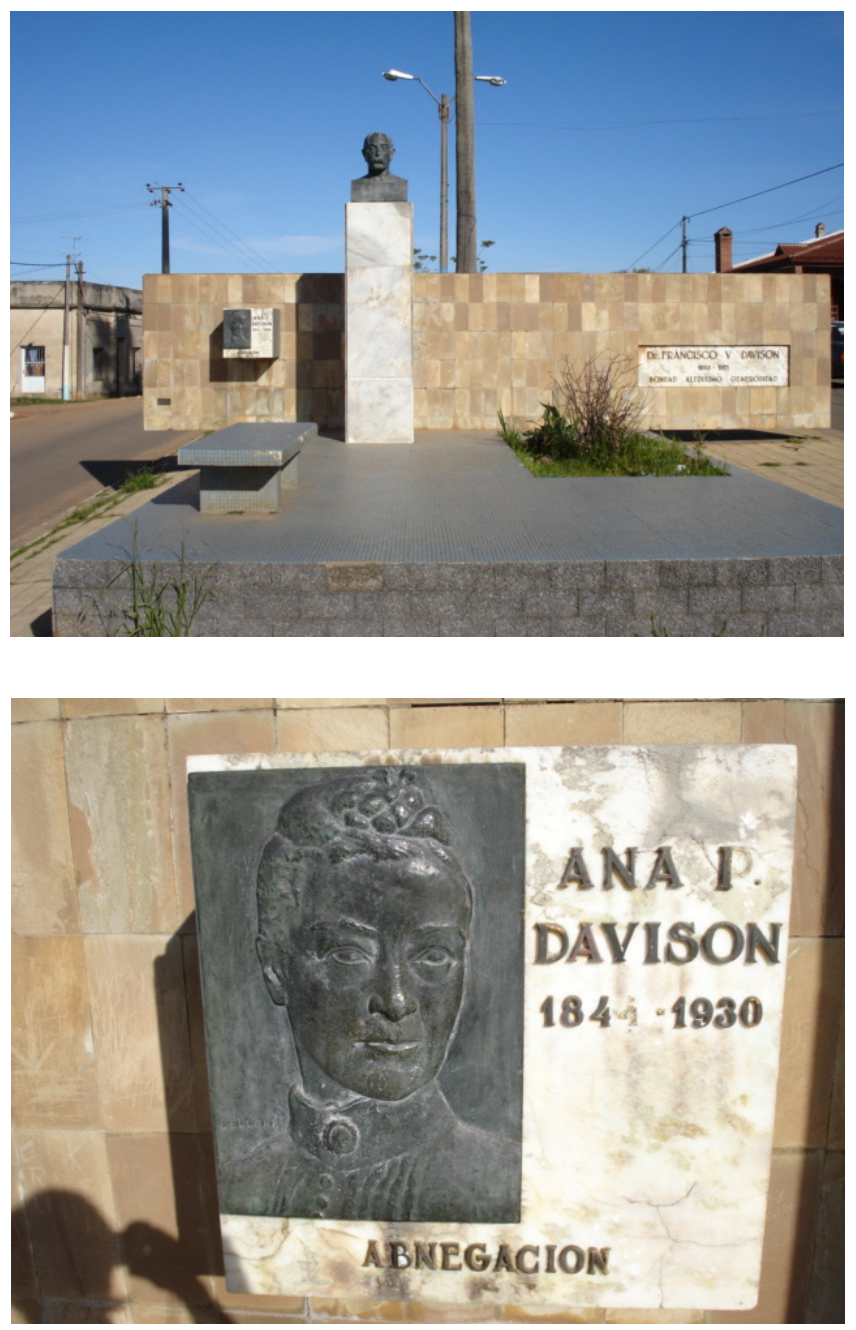

ali; na farmácia; e em um dos armazéns. Porém, em outros lugares, o português era considerado uma língua incompreensível, como era caso do único trailer que vende lanches na cidade. Estudantes das duas escolas públicas refletiam o que se notava nas ruas: entre eles, havia os que admitiam entender o português escrito e falado e outros que, abordados, negavam entender o português em qualquer modalidade. Apesar dessas posturas divergentes, músicas brasileiras e uruguaias tocavam nas rádios, uma atrás da outra, sem distinção, como se viessem do mesmo lugar, como se se tratassem de um idioma contíguo: a sonoridade dos ritmos fundia-se. Da mesma forma, não eram raras as vezes que os produtos alimentares estampavam seu nome em português e espanhol: 


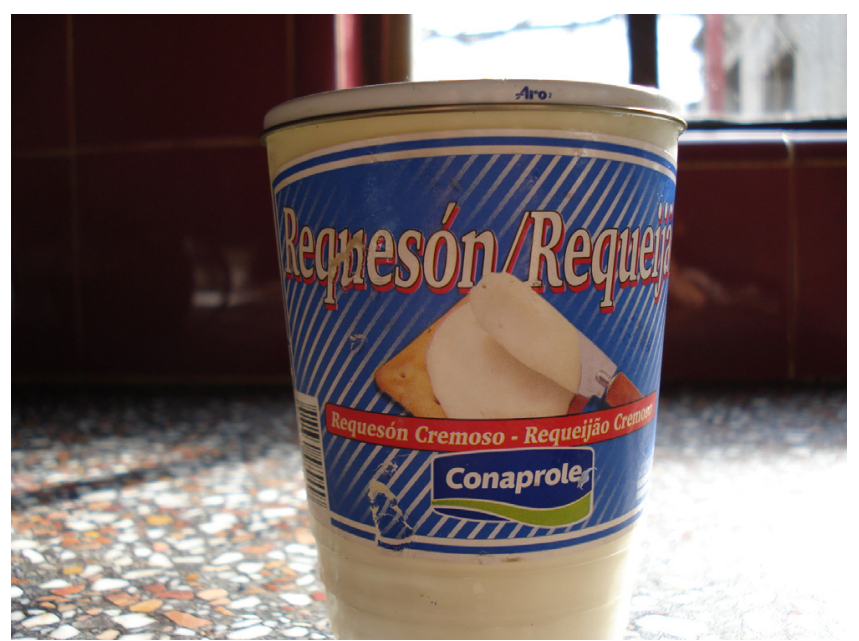

O português também estava presente no nome das pessoas, em panfletos, nos biscoitos, nas embalagens de chocolates brasileiros e em vários produtos vendidos na farmácia.

Alicia vivia imersa nas redes discursivas sobre a mulher bem-sucedida, sobre o bem-falar o espanhol como indício de uma mulher culta ou diferenciada, sobre temas brasileiros, como narrados por suas amigas brasileiras. Além disso, tinha descoberto os encantos do MSN e do Orkut para uma menina que queria ganhar o mundo conhecendo pessoas diferentes.

Em um dos encontros, Regina contou a ela um acidente grave que havia sofrido com seu carro na Vila de Moirones. O carro acabara-se em uma pista mal sinalizada e mal cuidada - uma questão política entre o governo do município e o do país, segundo os policiais rodoviários uruguaios explicaram a Regina. O modo como acontecera o acidente foi narrado a Alicia em português, com a mãe próxima a ambas. Em seguida, Regina pediu-lhe que escrevesse o que havia entendido do que lhe contara em português. No momento em que disse à menina que ela poderia escolher escrever em português ou em espanhol, já que a história havia lhe sido contada em português, a mãe imediatamente determinou: "Alicia, escreva em espanhol!". Foi aí que Regina confirmou a hipótese de que, de fato, Alicia tinha condições de escrever em português, caso contrário não teria ocorrido a imediata interdição materna.

A notação no topo do texto escaneado abaixo, “Escreva em espanhol!!”, foi realizada por Regina dias depois, para lembrar-se da advertência da mãe à menina. Os círculos, em torno de palavras e expressões na escrita de Alicia, foram realizados por Luis Behares, importante pesquisador uruguaio sobre a fronteira, que nos convidou para estar com seu grupo na Universidad de la 
República (UdelaR). Behares mostrou-nos as marcas e a presença do português na escrita de Alicia e as escreveu ao redor do texto, também dias depois de ter sido redigido por Alicia.

A seguir, o texto de Alicia:

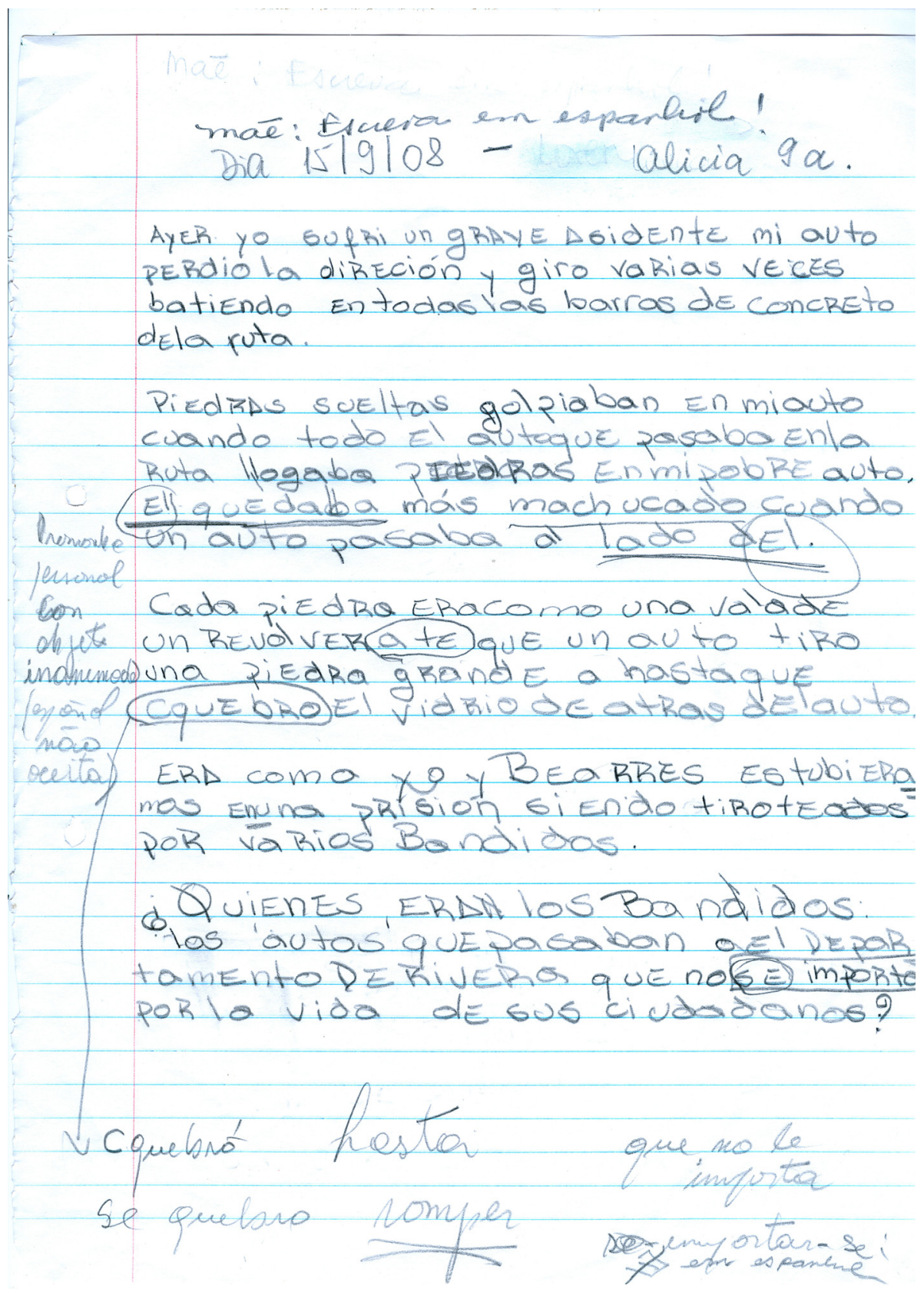

Pro-Posições, Campinas, v. 21, n. 3 (63), p. 97-115, set./dez. 2010 
A fim de tornar mais fácil para o leitor, transcrevemos abaixo o que se lê no texto.

\begin{abstract}
Ayer yo sufri un grave acidente mi auto perdio la direción y giro varias veces batiendo en todas las barras de concreto dela ruta. Piedras sueltas golpiaban en miauto cuando todo el autoque pasaba enla Ruta llogaba piedras en mi povre auto El quedaba más machucado cuando un auto pasaba al lado del.

Cada Piedra eracomo una valade un revolver ate que un auto tiro una piedra grande o hastaque cquebro el vidrio de atras delauto

ERA como yo y Bearres estubieramos enuna prisión siendo tiroteados por varios Bandidos.

¿Quienes ERAN los Bandidos los autos que pasaban o el Departamento De Rivera que no se importa por la vida de sus ciudadanos?
\end{abstract}

Lendo o texto de Alicia, encontramos o português que ela negava como sendo parte dela, mas que a tomava sem que se percebesse disso, sem que pudesse crer que havia nela uma conta a pagar para a nossa língua, que ela falava, que a fazia escrever e a escorregar em seu espanhol. Na menina, o espanhol "suja-se" com o português nosso (dela e nosso). Vejamos alguns exemplos retirados de sua/nossa narrativa:

O espanhol não aceita a expressão "el quedaba" referido a objeto inanimado (auto); o português sim... "Ele estava...". Da mesma forma, "ao lado dele" é uma forma de dizer em português, mas agramatical em espanhol em "al lado del". Um "e" foi omitido em "del", neste enunciado agramatical, que comporia "dele" no português negado em si, e que sim, seria gramatical, na língua denegada.

Para além desses exemplos, se a tomarmos em sua materialidade, a composição narrativa de Alicia pode ser vista como uma trama complexa e tensa, a lançar a expressão efetiva de sua voz em primeira pessoa e a apreensão da pretensa capacidade de entendimento dos fatos, por parte do leitor, em um jogo de esconde-esconde que, menos do que revelar, lança cada um deles em uma incontornável penumbra. Sob o efeito duplo das tensóes inscritas e circunscritas por um esforço de um uso instrumental da língua que, neste caso, por si mesmo se reduplica em sua capacidade de espalhamento, encontra-se, de um lado, um sujeito igualmente espalhado na pulverização de uma língua que não se contém em sua identidade; na outra margem, um sujeito-leitor deslocado dos níveis de relação de uma lógica perpassada por um princípio de identidade. O que se espalha, nesta estranha possibilidade de relação entre eles, não é o que meramente se espelharia na procura de uma imagem nítida ou de claro entendimento: o que é português, o que é espanhol, ou, ipso facto, onde há a coerência? 
Sem perder de vista o contexto da produção de Alicia, deparamo-nos com um transbordamento de relações com a língua que evidencia o seu trânsito incontrolável nos territórios de fluxos normativos. Há um imponderável em jogo, em toda esta situação, a impedir o mais audacioso ímpeto de averiguação a encontrar, a contento, o fio de Ariadne rompido, sabe-se lá como e por que motivos - se é que eles existem -, pelo fato de que a fronteira onde se vive pode ser menos a linha a separar e a delimitar que a linha a aproximar e a coexistencializar. Explicando-nos melhor, diríamos que, malgrado a oportunidade de escolher entre o português e o espanhol para poder narrar a história vivida por outra pessoa, Alicia é convocada por sua mãe a tomar o espanhol como forma de expressão. $\mathrm{O}$ agenciamento discursivo ativado pela autoridade materna e todo peso que isso pode representar consubstanciaram-se majoritariamente no texto dela. Mas, e isso é o que importa, assim como em toda fronteira, as linhas não são retilíneas, e as suas continuidades não representam incapacidade de desvios ou de buracos cavoucados por quem sobre elas circula, vemos a ordem soçobrar-se em um Yo que não se furtou a avizinhar-se com suas tensões em português.

Não podemos ignorar o fato de o episódio narrado a Alicia ter ocorrido em português. Que seria possível a ela a elaboração de um texto matizado neste idioma a respeito do acidente com o carro, temos condiçôes de afirmar que sim; que houve a interferência para que esta possibilidade não ocorresse, também o sabemos. $\mathrm{O}$ que se aloca na ordem do que não sabemos e nem poderemos saber, contudo, são as formas de sutis evasivas empregadas por ela em torno do imperativo de expressão que pretendia afirmar um tipo apenas de identidade: "escreva em espanhol!". O espantoso nesta situação não passa de efeito superficial do que devemos saber desde Lacan (2003, p. 24): "o sujeito é dividido pela linguagem como em toda parte, mas um de seus registros pode satisfazer-se com a referência à escrita, e o outro, com a fala".

Parece-nos que, de modo astucioso, a escrita forçada a falar em espanhol transfundiu-se em fala, para além da fronteira como limite, por uma escrita cujo transvio não é mero lapso, porém, afirmação de um sujeito que não se contentou apenas com um tipo de referência para satisfazer-se pela linguagem. Para Alicia, podemos cogitar que o extravio à ordem da mãe também é afirmação própria de uma singularidade que insiste em não estranhar-se com as múltiplas possibilidades de fazer-se circular no e com o fluxo provisório de experiências reveses ao estancamento linguístico. Para ela, a fronteira pode ter-se tornado a sua moradia heterotópica, sem, contudo, ter de ser um habitáculo pivotante. Nela, o estatuto provisório do sujeito pulsa na altercação das línguas que apenas testemunham o caráter erodido de toda identidade que insiste em não se fixar. Se não fosse assim, também não teria sentido o fato de que, desde Freud (1990, p. 84), "as fronteiras do ego não são permanentes". 
Nessa mesma direção, talvez, o traço cultural - representado pela mãe que tentou impelir o cálculo da língua para a afirmação de sua raiz espanhola se tenha equivocado em seu cômputo geral. Afinal, a fronteira indica muito bem que o próprio espaço comum dos encontros habituais pela busca de sentido por intermédio de qualquer modo de expressão se acha arruinado. Por isso mesmo, a língua miscigenada de Alicia pode tornar-se uma tipologia para as nossas inquietações perante tais heterotopias:

As heterotopias inquietam, sem dúvida porque solapam secretamente a linguagem, porque impedem de nomear isto e aquilo, porque fracionam os nomes comuns ou os emaranham, porque arruínam de antemão a "sintaxe", e não somente aquela que constrói as frases - aquela, menos manifesta, que autoriza "manter juntos" (ao lado e em frente uma das outras) as palavras e as coisas. (Foucault, 1999, p. XIII)

Um tanto trêmulos, descobrimo-nos na vertigem da língua fora de controle, a solapar a ordem externa dada ao sujeito, busca insistente em contingenciar sua identidade que, entretanto, será posta em xeque pela própria recusa incalculável do sujeito, que insiste em fazer da língua a expressão mais viva do que nele é incontornável: a sua própria expressão de lugar sem-lugar. Sujeito sem transparência às regras evidentes do uso dos bons termos e das boas coerências.

Tomemos os seguintes termos do sujeito que anuncia: cada piedra eracomo una vala de un revolver ate que un auto tiro una piedra grande a hastaque quebro el vidrio de otros delauto. A frase, tal como Foucault sugeriu acima, emaranha e fraciona os nomes comuns numa ordem cuja correspondência não tem a pretensão coerente de uso exclusivo de expressão em apenas uma língua. Ao contrário, ao abrir-se ao fluxo constante de um intercâmbio entre espanhol e português, a frase vale-se de uma sintaxe criadora de sentido, todavia sem purismos e pudores, que afirma o trânsito permanente do sujeito que vive a fronteira. Por conseguinte, o anúncio é mais do que a pretensa correspondência entre o sujeito e a coisa dita; é também manifestação erodida de que a(s) própria(s) língua(s), sob o curso incontinente de seu(s) próprio(s) transbordamento(s), destitui(em) o próprio sujeito que a(s) instaurou.

Notemos bem: cada piedra era como una vala de un revolver ate [...]. O óbvio deslize prenunciador do trânsito fluido das línguas que se confundem à guisa da construção de um sentido, à primeira vista, justifica-se pela preposição portuguesa "ate" [até], utilizada com o intuito de expressar um limite posterior no tempo da ação. Quer dizer, valendo-se do "ate" e não de um hasta, encontramos o marco que vira a história: os demais carros apenas pararam a partir do instante que uma grande pedra foi lançada sobre eles, e não com o intuito de que seus ocupantes pudessem ajudar a acidentada. 
Eis que somos, entretanto, destituídos de uma compreensão de sentido aparentemente corriqueira por um peso comparativo, cujo poder de fogo é destruidor: cada piedra era como una vala de un revolver. Onde português, onde espanhol? Excluídos os presumíveis equívocos de um sujeito escritor de 9 anos de idade, que teria esquecido de acentuar a palavra revólver, cuja grafia é a mesma em ambos os idiomas, e que teria operado por lapso em vala, quando o correto, mais uma vez nos dois idiomas, seria bala, o que temos? A princípio, sugere a conduta lógica, deparamo-nos com uma comparação resguardada no imaginário infantil, consciente do que um projétil de um revólver é capaz de fazer: destruir. Mas isto apenas no registro da ordem agenciadora inicial interposta a Alicia: "escreva em espanhol"; e se lermos: cada piedra era como una vala de un revolver como espanhol.

Em outra perspectiva, contudo, os termos, apesar de manterem-se no âmbito da comparação, função precípua da frase, se apreendidos em português, iluminam uma região diferente de sentidos. Dessa forma, cada pedra torna-se uma vala de un revolver. A esta altura a língua funciona como uma porta giratória alucinante: saídas e entradas de sentidos dependem apenas da relação com o intercâmbio das referências pelas quais os termos circulam, sem, contudo, prejudicar a força de uma comparação. Cada pedra, "como uma vala de revolver”, punha tudo em desordem, desarrumando e revirando a sucessão dos acontecimentos. Eis aí um dos sentidos próprios para revolver.

Seja como for, parece-nos que somos mesmo lançados em uma vala de revolver, em que o encadeamento dos sentidos tem por função ulterior ativar a recusa transparente de sentidos a partir do sujeito que anuncia. Por conseguinte, mais do que destituir o sujeito que tentou instaurar uma possibilidade de força comparativa para o entendimento e um relacionar-se com um acontecimento, de igual modo, a língua opera destituindo o sujeito como intérprete seguro e eficaz daquela alocução. Ambos se encontram, nessa vala, revolvidos, pois o dito e o não dito impedem, economicamente, a permanência, por parte desses sujeitos, no mesmo lugar. Língua e sujeito confundem-se como palavras que nascem em fronteiras que não possuem delimitações nem evidentes, nem límpidas, pois a ordem de ambos é revirada incessantemente. Sujeito e palavra, palavra e sujeito, assim, são, de modo miscível, conspurcados:

\section{Nascimento da palavra \\ Teve a semente que atravessar panos podres, criames De insetos, couros, gravetos, pedras, ossarias de peixes, Cacos de vidro etc. - antes de irromper. \\ (Barros, 2009, p. 11).}

Com efeito, toda palavra que irrompe é, desde a sua emersão, uma fronteira, quer dizer, ela se encontra por entre, nesse atravessar constante que lhe nega 
uma pureza identitária. A sensibilidade de Manuel de Barros permite-nos entrever as açóes de furo que são próprias da palavra desde a sua letra. Ao passo que a palavra rompe, surgem valas como marcas da habitação de quem fala, imediatamente reviradas por outras palavras: "a letra como conseqüência, e linguagem, precisamente pelo que digo: que esta é habitada por quem fala" (Lacan, 2003, p. 19). Eis um efeito imediato a desdobrar-se em bifurcação que compromete qualquer medida unitária em torno do sujeito, já que ele fala: "Não é a letra... litoral, mais propriamente, ou seja, figurando que um campo inteiro serve de fronteira para o outro, por serem eles estrangeiros, a ponto de não serem recíprocos? A borda do furo no saber, não é isso que ela desenha?" (Ibidem, p. 18, grifos nossos).

Então é uma bala de revólver ou uma vala de revolver que se anuncia? Eisnos, como estrangeiros, na fronteira destas palavras que furam o nosso saber a respeito do que, enfim, poderiam anunciar e, mais ainda, do que poderíamos auscultar. Eis-nos, então, como sujeitos sem identidade. Mas isso somente seria motivo de consternação pelo costume que temos de circular por onde existem rígidos controles alfandegários. Nesse sentido, é necessário superar todo o nosso "vício de ocularidade", valendo-nos de um bom termo de Bachelard (1978), porque a língua não visa sintetizar a expressão acabada de seu termo, nem de um pretenso sujeito dela anunciador. O nosso engano é o de pensar que a fronteira é um lugar. Ao contrário, a fronteira representa o não lugar, pois é dispersão, ou melhor, ainda, é o atravessar. Portanto, um processo que pulveriza o sujeito como identidade assumida, chancelando-lhe uma modificação em seu próprio status, tal como ele pode assumir, ao dizer $Y o$ ou Eu, ou os dois.

De certo modo, isso fica mais explícito na pergunta que um garoto de 12 anos faz a Carlos Alberto Potoko. Nela encontramos o jogo de ser ou não ser que lança o sujeito para a dimensão da fronteira entre "eu" e um "outro" eu. Potoko é brasileiro, impuro como tantos outros, membro da Academia de Letras de Santana do Livramento e servidor público dessa cidade. Realiza trabalho de literatura brasileira em escolas do município brasileiro que faz divisa, também mesclada, com Rivera, território uruguaio. Em certo dia, pediram-lhe para, antes de sua aula, dar e pedir a seus alunos um formulário onde, em um dos itens, solicitava-se aos estudantes que definissem sua nacionalidade. Carlos, para cumprir o que lhe havia sido solicitado, antes de iniciar sua aula, pediu aos estudantes para preencherem o formulário. João levantou a mão no ato de escrita do campo "nacionalidade". Estava indeciso. Não sabia, ao certo, se era brasileiro ou uruguaio. "O que e quem eu sou, professor: brasileiro ou uruguaio?", perguntou o menino a Carlos. Havia nascido no Uruguai. Sua mãe era uruguaia. Havia se mudado para o Brasil, país do pai. Era também brasileiro. Morava em Santana do Livramento e tinha amigos uruguaios e brasileiros. 
Estudava no Brasil, mas "vivia" ("estava constantemente") no Uruguai. Então o que, ou quem, ele era?

- "Então professor, me diga, sou brasileiro ou uruguaio?"

Carlos, tomado de surpresa por aquela pergunta, respondeu: "O que seu coraçãozinho the diz? Você é brasileiro ou uruguaio, João?".

João: "Por enquanto, sou brasileiro".

Este "por enquanto" encarna a volatilidade e a mutabilidade de ser o sujeito um devir permanente. Por enquanto... brasileiro.

\section{Considerações finais, por enquanto}

O imponderável da fronteira encontra-se nos acontecimentos possíveis de sua transigência que, no lugar de delimitar um território qualquer, estende a sua cartografia por passagens que, em um dado momento, mesclam e combinam com(posições) de espaço e de tempo. A fronteira é uma ficção, portanto. É um nome dado a linhas abstratas que, na realidade, não existem como são; turvamento contínuo do que lhe escapa incessantemente: microfísica de mobilidades contínuas.

Pensemos na fronteira da língua, do sujeito, de suas causas e efeitos conscientes e inconscientes, pensemos nas corruptelas da linguagem, na pedra que rola de um lugar para o outro - a quem pertence? Ao sul, ao norte? Se precisamos, por vezes, de unidades coerentes para processar a identidade das coisas a serem nomeadas, ditas, pensadas, trabalhadas, sumarizadas, isso não quer dizer que as coisas sejam assim. Escorregamos o tempo todo entre a capacidade e a incapacidade da clareza, simplesmente porque o que temos são clarões em nossa própria fronteira racional nada evidente.

$\mathrm{O}$ que tentamos exercitar neste texto foi justamente isto: nem a língua, menos a linguagem, nem o sujeito, nem as ambiçôes de identidades nacionais esgotam nossas delimitações. "A existência não é uma função monótona", alertara-nos Bachelard (1978, p. 32). O mesmo é válido para a fronteira e para os seus coexistentes: ela realça o grão da monotonia, denunciada pela escrita de Alicia, por intermédio do furo nas certezas da identidade, efeito da indagação de João, por esses habitantes da fronteira. Mas eis novamente uma armadilha: todos somos, incontornavelmente, seres de uma fronteira:

O homem é um modo de ser tal qual nele se funda esta dimensão sempre aberta, jamais delimitada de uma vez por todas, mas indefinidamente percorrida, que vai, de uma parte dele mesmo que ele não reflete num cogito, ao ato de pensamento pelo qual a capta e que, inversamente, vai desta pura captação ao atravancamento empírico, à ascensão desordenada dos conteú- 
dos, ao desvio das experiências que escapam a si mesmas, a todo horizonte silencioso do que se dá na extensão movediça do nãopensado [...] o homem é também o lugar do desconhecimento (Foucault, 1999, p. 445).

Aqui, contudo, caberia a questão: por enquanto? Diante da charada infantil, pensamos ser legítimo arriscar o início de uma resposta. Ela seria afirmativa, por encanto...

\section{Referências bibliográficas}

BACHELARD, G. Obras incompletas. São Paulo: Abril Cultural, 1978. (Coleção Os pensadores).

BARROS, M. Oguardador de águas. São Paulo/Rio de Janeiro: Record, 2009.

BROVETTO, C.; GEYMONAT, J.; BRIAN, N. (Org.). Português del Uruguay y educación bilíngüe. Montevidéu: ANEP - CEP, 2007.

CHOMSKY, N. Aspects of the theory of syntax. Cambridge, Mass: M.I.T. Press, 1965.

FOUCAULT, M. As palavras e as coisas. São Paulo: Martins Fontes, 1999.

FREUD, S. O mal-estar na civilização. In: FREUD, S. Edição standard brasileira das obras psicológicas completas. 3. ed. Rio de Janeiro: Imago, 1990. v. 21.

LACAN, J. Outros escritos. Rio de Janeiro: Jorge Zahar, 2003.

LÍNGUA, vidas em português. Direção de Victor Lopes. Produção de Renato Pereira, Suely Weller e Paulo Trancoso. Brasil-Portugal: Tv Zero Sambascope; Costa do Castelo Filmes; Paris Filmes, 2002. 1 DVD (105 min), son., color.

ORLANDI, E. Lingua brasileira e outras histórias. Discurso sobre a língua e ensino no Brasil. Campinas: RG, 2009.

PEI, M. The story of language. Filadélfia: J.B. Lippincolt Co, 1965.

RAJAGOPALAN, K. O conceito de identidade em lingüística: é chegada a hora para uma reconsideração radical. In: SIGNORINI, I. (Org.). Lingua(gem) e identidade. Campinas: Mercado de Letras, 1998.

RIBEIRO, João Ubaldo. Língua: vidas em português. Disponível em: <http:// www.almacarioca.com.br/lingua.htm>. Último acesso em: 15 maio 2010.

RUSHDIE, S. In good faith. Londres: Granta, 1989.

SAUSSURE, F. Curso de lingüistica geral. São Paulo: Cultrix, 1993.

VELOSO, C. Lingua. Disponível em: <http://letras.terra.com.br/caetano-veloso/44738/>. Último acesso em: 27 maio 2010.

Recebido em 04 de fevereiro de 2010 e aprovado em 07 de julho de 2010. 